\title{
Comparative Analysis of Islamic and Conventional Mutual Funds' Performance during Financial Crisis and Non-crisis Periods in Pakistan
}

\section{Imran Ahmed ${ }^{*}$, Danish Ahmed Siddiqui ${ }^{2}$}

${ }^{1}$ Research Scholar, Karachi University Business School, University of Karachi, Karachi, PAKISTAN

${ }^{2}$ Associate Professor, Karachi University Business School, University of Karachi, Karachi, PAKISTAN

Corresponding Contact:

Email: Imran.ahmed790@yahoo.com

\begin{abstract}
This study aims to analyze and investigates the differences in performance of Islamic and conventional mutual funds in three periods, namely the period during the financial crisis period, dated 2008 to 2009, after crises period 2010 to 2017, and the whole period, dated from 2007 to 2017. More specifically the study aims to investigate whether the Shariah compliant Equity, Income and Assets Allocation Mutual funds performed better in terms of risk adjusted basis as compared to the conventional Equity, Income and asset allocation mutual funds. The risk return behaviors were examined by employing performance measures such as Sharpe, Treynor, and Jensen Alpha. Moreover, their performance in coping of systematic risk is also analyzed by regressing macroeconomic variables on returns. Study concluded that Conventional Income mutual funds perform better in all three periods including (crises and non-crises) compare to its counterpart Islamic income mutual funds in both risks adjusted basis and simple arithmetic mean basis, however their difference is not statistically significant. Study also found that Islamic equity mutual funds perform better in crises period as compare to its conventional equity mutual funds in risk adjusted basis In crises period both funds gave negative return, but Islamic equity mutual funds declined less than conventional mutual funds which shows that Islamic mutual funds provide better hedging in crises period., however there were no significant difference among the two in the other two periods. Similarly, Assets Allocation funds also have no significant difference among themselves, however Islamic asset allocation mutual funds outperform conventional asset allocation mutual funds in all three periods, especially in crises period where Islamic funds showing positive returns as compared to conventional fund that were suffering in loss of about $14 \%$. Overall the whole period performance of Islamic mutual funds is slightly better but not statically difference.
\end{abstract}

Key Words: Mutual funds, financial crisis, risk, equity, income, asset return, net asset value, t-test 


\section{INTRODUCTION}

The Islamic finance industry has been growing rapidly over the decade, increasing at 10$12 \%$ annually. Today, Shariah-compliant financial assets are come up estimated at roughly US\$2 trillion, covering banking and non-bank financial institutions, capital markets, money markets and insurance ("Takaful"). In numerous dominant part Muslim nations, Islamic financial assets have been mounting faster than conventional banking assets. There has also been a flow of interest in Islamic finance from all over the world including non-Muslim countries such as the UK, Luxembourg, South Africa, and Hong Kong.

Islamic finance has appeared as a valuable tool for financing development worldwide over the past decade, as well as in non-Muslim countries. Major financial markets are seeing hard evidence that Islamic finance has already been mainstreamed within the global financial system - and that it has the potential to grow and to help address the challenges of ending life-threatening poverty and enhancing shared prosperity. Islamic finance is based on Shariah rule, asset-backed, ethical, sustainable, environmentally- and socially-responsible finance. It promotes risk sharing, profit sharing and connects the financial sector with the real economy, and stresses financial inclusion and social welfare. The Islamic Equity market has been established based on five main principles of operations; stopping any practice of usury, sharing risks, preventing widespread speculation, activity and contracts must be in compliant with the stated Shariah Law.

Therefore, it is anticipated that risk of Islamic financial industry may be lower especially in financial crises period than conventional financial industry. Some studies concluded that screening criteria does impact positively to return and diversification, which may lead Islamic Financial industries to lower returns for given portfolio risk. 2008 financial crises almost destroyed the financial systems around the world, Islamic financial systems were relatively untouched, protected by their fundamental functional principles of risk and profit sharing and the avoidance of leverage and speculative financial instruments.

Beck et al. (2013) concluded that during the global financial crisis 2008-9, Islamic banks had a higher intermediation ratio, higher asset quality and were better capitalized, while the conventional financial industry was shattering. Conventional financial industry declined by $35-40$ percent, but Islamic Financial institutions were dropped by almost 10\%. Most studies documented different results on the performance of Islamic mutual funds and conventional mutual funds. Some studies found that Islamic stocks performed better than conventional stocks, gave higher returns and well diversified (Hussein, 2005; Hussein and Omran, 2005). On the other hand, Hoepner et al. (2009) concluded in their studies by using data set of 262 Islamic equity funds from 20 countries that Islamic funds only over performed to its benchmark in only three countries and significantly underperformed in eight western countries and the performance of other 9 countries were statically indifference. Saud et al. (2017) concluded Islamic mutual funds in Pakistan are found riskier and provide fewer returns as compared to conventional mutual funds.

Pakistan is unique country in many regards, firstly it a developing country where financial markets and products are still in a developing phase. Secondly, it also has a huge infrastructure of both Islamic and conventional financial institutions and products. And thirdly mutual funds industry developing fast and almost at equal footings with their conventional counterparts. For all these factors, it makes Pakistan unique place among other countries. No research has been done in context of Pakistan about three major type of comparative analysis of Shariah compliant mutual funds and Conventional mutual funds 
especially in three different period namely, crisis and non-crises, whole period. This study filled that gap moreover gave a comparative analysis between Islamic and conventional funds of Equity, Income funds (Sukuk in Islamic finance) and mixture of both funds. Both funds followed portfolio theory and assumed to have no significant difference, the only difference seems to be in legal nature that prohibit firm that engaged in non-shariah compliant activities to be included in funds. Whether this culminates into real structural difference given them unique identity has yet to be seen. This highlights the need to Comparative Analysis of Islamic and conventional mutual funds' performance in three different period during financial crisis, non-crisis and whole periods in Pakistan.

This study adds to existing literature in more comprehensive way because most studies focus only one type of comparison, shariah complaint stock (index) and conventional stock (index). However, our study is more comprehensive comparison of conventional Equity Index with its Islamic Index, conventional Fixed Income with its counterpart Islamic Fixed Income (Sukuk in Islamic Finance) and Convention mixture of fixed income and equity called Asset Allocation funds with its counterpart called shariah compliant Asset Allocation mutual funds in Pakistan. Covering all three major type of period, namely, crises period, non-crises period and whole period. The study also will create some avenue to the investors of non-banking financial institution to oversee the performance measures of different types of funds in risk adjusted basis. Why investors choose IMFs or Conventional Mutual funds for their resources.

\section{Objectives}

In this research the study aims to analyze and compare the performance of Islamic mutual funds and conventional mutual funds. Particularly, the main of this research in the context of research questions are as follows:

- To measure the performance of three different type of Islamic mutual funds and conventional mutual funds whole period 2007-2017

- To analyze the difference among performance of three different type of Islamic and conventional mutual funds in crisis period. (2008-2009)

- To analyze the performance difference among three different type of Islamic and conventional mutual funds in non-crisis period. (2010-2017)

\section{Research Question}

Proceeding from the foregoing purposes to attain the objective of the study, the current study was guided by the following question:

$\mathrm{RQ}_{1} \quad$ Is performance of Islamic mutual fund is different from conventional mutual funds?

To investigate the differences in performance of three different type of Islamic and conventional mutual funds in three periods, namely the period during the financial crisis period, dated 2008 to 2009, and the period after the financial crisis, dated from 2010 to 2017 and whole period 2007 to 2017.

\section{Hypothesis}

$\mathrm{H}_{1}$ The Returns of Shariah compliant equity, income and assets allocation funds are significantly different from its conventional counterpart.

$\mathrm{H}_{2}$ These Shariah compliant mutual funds provide better hedging in crises period.

$\mathrm{H}_{3}$ These Shariah compliant mutual funds outperform risk adjusted basis from its counterpart during non-crises period. 
In the following section, the previous studies related to the research objectives are briefly discussed. In section 3, theoretical background of the study is discussed. In Section 4, the data and method of this study is discussed, and the methods employed to accomplish the objectives are explained and the research questions of this study are answered. Section 5 discusses the results of data that we have analyzed through different statistical and econometric techniques related to the methods of study. In the last section, some conclusions are drawn which elaborate the major findings of the research followed by the key conclusion and recommendations. It also elaborates the performance of Islamic and conventional mutual funds in the context of Pakistan economy.

\section{LITERATURE REVIEW}

In this section of study, a detail discussion of literatures regarding Islamic and conventional mutual funds will be provided. Saud et al., (2017) compared the performance of the Islamic financial institutions to conventional financial institutions in Pakistan for the period 2006 to 2016, Employed GARCH model and concluded in their study that Islamic mutual funds are found to be risky and provide fewer returns as compared to conventional mutual funds. Mohsina et al. (2014) analyzed and compare the performance of Shariah complaint and conventional index in India, period for their study was June 2009 to May 2014 and the index they took was S\&P BSE 500 Shariah and S\&P BSE 500. Study used time series to calculate monthly average return and risk adjusted return. Study revealed that Conventional index slightly outperformed Islamic during the study period. However, the Islamic Index is found far less risky than its counterpart Index. Hesham et al., (2010) evaluate Islamic and conventional mutual funds for the period January 2003 to January 2010, mutual funds used for the study was managed by HSBC, the fourth largest fund manager in Saudi Arabia. Study employed a number of performance measures such as Sharpe, Treynor, Jensen Alpha and their variants to observe risk returned behavior, to analyze and find difference in performance, sample divided in four periods such as full period, bull period, bearish period and financial crisis period Study finds Islamic funds underperform Conventional funds during full period and bullish period, but they outperform conventional funds during bearish and financial crisis period, further conclude that Islamic mutual funds provide better hedging during economic downturns.

Shaliza et al., (2017) studied the performance of 200 Islamic mutual funds and conventional mutual funds in Malaysia equity market from 2007-2015 and further period divided in financial crisis from 2007-2008 and 2007-2015 (full period), found no significant difference in performance in full period between Islamic and conventional mutual funds and concluded IMFs performed slightly better than CMFs for both periods. IMFs showed less negative as compare to CMFs in crises period. Dharani and Natarajan (2011) compares and analyze the risk and return behavior of Shariah compliant index (Nifty Shariah index) and Conventional index (Nifty index) on daily, monthly and quarterly basis, period of study was from 2nd January 2007 to 31st December 2010. Study Employed t- test to compare the mean returns difference between both indices. Study concluded that there is no performance difference between Nifty Shariah index and Nifty Index on average daily, monthly and quarterly basis during the study period.

Sejarah (2015) compares the performance between Jakarta Islamic Index and non-Islamic index for the period split into two periods, 2005 to 2007 and 2008-2012, employed Capital Asset Pricing Model (CAPM) single index model extended to the Fama and French three factors and research concluded that there is no significant performance difference between 
Jakarta Islamic Index and Jakarta and non-Islamic Index. Banani and Hidayatun (2017) compares the performance of Islamic index with its counterpart in two developing countries, Indonesia and Turkey for the period 2010 to 2014, study employed Sharpe, Treynor and Jensen Alpha to measure risk adjusted performance, study concluded that Islamic index in Indonesia significantly outperformed to its counterpart and Turkey Islamic index insignificantly underperformed to its counterpart. Nasir et al. (2012) investigates 9 Islamic mutual funds of Pakistan on risk adjusted basis, employed sharp ratio, Treynor ratio, Jensen's Alpha and information ratio for the year 2009-2010 on daily basis. Study concluded that Islamic mutual funds underperformed to market. Yacine et al. (2017) observes the performance of Shariah Compliant mutual funds. They have low value at risk and high sharp ration in crises period. The results confirm that Islamic mutual funds provide hedging opportunity against crises.

Osamah et al. (2015) examined the 9 Islamic indices and 9 conventional indices of AsiaPacific, Canadian, Developed Country, Emerging, European, Global, Japanese, UK, and United States for the period 1997-2012 and revealed that overall conventional indices performed efficiently, during crises period, Islamic indices performed slightly efficient than conventional indices. Zia-ur-Rehman et al. (2015) inspect the performance relationship between Islamic and conventional equity funds in Pakistan for the period 2007 to 2014. Study revealed no significant difference between Islamic and conventional and both funds underperformed market. Islamic funds performed better in crises period which indicate it provides hedging opportunity.

Bilal et al. (2018) examines performance and Islamic and conventional mutual funds besides other for the period 2009-2013, employed Treynor and other techniques to measure risk adjusted performance. Study revealed that Islamic mutual funds performed better than conventional mutual funds in earning and risk adjusted basis. Issam and Moustapha (2016) constructed Islamic stock index in Morocco as per Shariah screening methodologies to examine the performance of Islamic and conventional index for the period January 2013 to December 2014. Study found Islamic index well diversified and Islamic index outperformed broad-based Moroccan All Shares Index (MASI) during the study period. Statman (2000) analyzed the performance mutual funds of the Domini social index (DSI) against the performance of S \& P 500 companies in the US for the period of 1990-98. He concluded that the raw returns and risk for DSI were higher than S \& P 500 and vice versa for the returns adjusted risk. On the other hand, social funds found to be less risky and to have lower returns than the DSI and the S \& P 500. Hussein (2005) analyzed the performance of the Islamic index in the Dow Jones against the Dow Jones index for the period of 1995- 2003. They concluded that the Islamic index outperformed the conventional index both in the entire and bull periods. Hussein (2005) inspected the effect of screening on the performance of Shariah compliant index and conventional index, Study took FTSE Global Islamic Index and DJIMI as shariah compliant index against its counterpart index, Dow Jones World Index and FTSE All-World Index, in both the short and long-run basis. Study concluded that the Islamic index outperform to its all counterpart index during the entire period. Moreover, performance of the Islamic index in bull was significantly positive. Therefore, he concludes that the Islamic screening has positive effect and favorable effect on the performance index.

Hoepner et.al, (2009) concluded in their studies by using data set of 262 Islamic equity funds from 20 countries that Islamic funds only over performed to its benchmark in only three countries and significantly underperformed in eight western countries and the performance of other 9 countries were statically indifference. Elfakhani et al., (2005) compared the 
performance of the Islamic mutual and conventional mutual funds in several emerging countries. Study finds no statistically significant difference between Islamic and conventional funds. Therefore, the screening mechanism does not affect negatively on the performance of Islamic investments. Fikriyah et al., (2007) concluded that in Malaysia, during bearish and bullish trend performance of Islamic and conventional mutual funds differ. Therefore, during bearish economic trend the performance of Islamic mutual funds is better. Conventional mutual funds performed better than Islamic counterparts during bullish economic trend. Abderrezak (2008) investigated the Performance of Islamic mutual funds against conventional mutual funds and concluded that performance of Islamic mutual funds was poor against benchmark indices. Selectivity skills of mutual fund managers were also poor. The lower diversification is the main cause of poor performance of Islamic mutual funds. Hayat and Kraeussl (2011) concluded that Islamic equity mutual funds underperformed to its benchmark and as well as conventional benchmark all over the world. Performances of Islamic mutual fund managers are found to be poor in terms of selectivity and timing.

\section{THEORETICAL BACKGROUND OF ISLAMIC AND CONVENTIONAL MutUAL FUndS}

The Islamic finance industry has been growing rapidly over the decade, increasing at 10$12 \%$ annually. Today, Shariah-compliant financial assets are come up estimated at roughly US\$2 trillion, covering banking and non-bank financial institutions, capital markets, money markets and insurance ("Takaful"). Islamic finance is based only Shariah law, The Shariah encourages the use of profit sharing and partnership schemes, and forbids interest (riba), gambling and pure games of chance (maysir), and short selling (gharar: selling something that is not owned or that cannot be described in accurate detail; i.e., in terms of type, size, and amount). Conventional intermediation is based on interest to a large extent and permits for the transfer of risk. On the contrary, Islamic intermediation is asset-based, and is based on the sharing of risk and reward between the participants viz. the depositor, bank, and the entrepreneur. The Islamic Equity market started growing in the mid-90s although it is around us for last 40 years until 1999, there was no official Islamic index to benchmark the returns of Islamic Equity Funds against. In 1999 first two Islamic indices launched, Dow Jones and FTSE, Dow Jones Islamic Market Index (DJIMI) and the FTSE Global Islamic Index Series (GIIS) respectively. Nowadays, apart from Dow Jones and FTSE, MSCI Barra and Standard \& Poor's also offer numerous Islamic equity indices.

Particularly due to the recent surge of liquidity in all over world Islamic finance is gaining significant place in the finance market place. This in line is attracting both domestic and international money managers for tapping this market by offering Shariah-compliant funds. Indices were introduced world-over; even many financial institutions of developed countries such as Citibank, Barclays, Morgan Stanley, Merrill Lynch and HSBC are selling Islamic financial products. In India also the Standard \& Poor's launched S\&P BSE 500 shariah with the partnership of S\&P Dow Jones and Bombay Stock Exchange. The S\&P BSE 500 consists of 500 most liquid and largest Indian stocks trading at the BSE. The number of Shariah-compliant stocks in India is much higher than in Muslim countries put together, thus providing larger scope for Muslim investors. 61 per cent Indian companies are found Shariah-compliant in India against 57 per cent in Malaysia, 51 per cent in Pakistan and a mere 6 per cent in Bahrain.

Additionally, many well know American and UK based stock exchanges like New York Stock Exchange and London Stock Exchange have launched Islamic indexes to monitor the performance of Shariah compliant firms which operate as per the Islamic based investment guidelines. 


\section{Types of Mutual of funds}

Mutual funds are categorized into following types based on risk and time. By and large following three main categories (income, equity and mixed).

1. Income Funds: These are of the following types

a. Money market funds: This type of funds consists of risk-free or no risk short term securities. It gives very low yield. They invest usually in government short term securities, T-bills, certificate of deposit etc. It provides security of principal amount and but gives very low return.

b. Income funds: It consists of government and investment category corporate bonds. Its gives moderate yield as per risk basis. This type of investment takes low risk but investment holding period is long. Investor of these mutual funds wants steady income until maturity. They are risk averse.

c. Bonds funds: Every type of corporate bonds is part of this mutual funds. This type of funds is actively managed to buy undervalued bonds and sell overvalued bonds. Return of this mutual fund is high as compare to income funds but bears higher risk than income funds. Junk and speculative bonds give high return with high risk. Objective of this funds is usually to get capital gain rather than steady income.

Nowadays, Shariah compliant Income funds are also offering regular and steady Income. These funds invest in Shariah compliant fixed income securities such as Sukuk.

2. Equity Funds: This type of funds can categorize also in terms of risk, objective and investment period basis. Generally, below are major types. They invest in equity market and the aim of equity funds is to gain high return as compare to fixed income funds. It carries high risk also and risk of loss of money also exist. High return with capital appreciation creates different type portfolio and steady regular income with moderate risk create different type of mutual fund so it's totally depended on objective of investor and style of portfolio manager. Shariah compliant Equity mutual funds are created to invest in those stocks which are shariah complaint. Shariah compliant investment board has maintained list of stock and regularly updating list of shariah complaint stocks. Nowadays in almost every country including Pakistan, Shariah compliant index has been created including Dow Joan, S \& P-500.

3. Balanced funds: It is the mixture of fixed income and equity securities to diversify risk and to get return objective. It is also called Asset Allocation Funds. These funds usually have $50 \%$ weight in equities and $50 \%$ in fixed income securities in moderate style. If weight is around $70 \%$ to equity and $30 \%$ for fixed income than it become aggressive asset allocation and its opposite, $30 \%$ for equity and $70 \%$ in fixed income than it is called conservative approach for Asset Allocation mutual funds. In our study we took the moderate approach data analyzed it with counterpart shariah compliant Asset Allocation Mutual Funds.

\section{Basic principal of Shariah Compliant (Islamic) Screening Criteria of Stocks}

As per Islamic principal, buying and selling share or stocks of the company is perfectly legal but depends upon share of which company we are buying or selling. Keep in mind buying shares means you are becoming stock holder of the company or taking the ownership of the company as per proportionate of your share percentage. As per Islamic principles, Islamic scholars all over the world have defined basic guidelines to judge stock whether it falls under the Shariah compliant stock or not. 
- Core business of the company: Main Business of the company must be Halal. It must not be haram business-like liquor, gambling, pork, pornography or any other haram business. It must not be any Riba (Interest) related business like conventional banks, insurance, leasing companies.

- Proportion of Prohibited Income: If a company has more than one business and any one has haram business as per Islamic law than proportion of haram business will be calculated. Haram business must not be more than 5\% and all stock holders must raise this issue in AGM to close haram business. If dividend received by stock holder than proportion of haram must be given in charity.

- Debt to Equity Ratio: As per Islamic principal, interest bearing debt investment is prohibited. However, scholar have included the company for investment who has debt to equity is not more than $33 \%$. Mostly shariah compliant index excluded that company who has debt to equity ratio is more than 33\% including Dow Jones Islamic Market Index, FTSE Islamic Index. As per Islamic principal, Preferred stocks are considered interest bearing debts. Dividend for preferred stock is interest and it's prohibited in Islam.

- Debt to Total Assets: Zero coupon bonds, Fixed Income Bonds, preferred stock is considered interest bearing debt. Islamic scholar has defined that Debt to Asset ratio should be less than $37 \%$.

- Liquid Assets to Total Assets: Cash or cash equivalent assets to total assets should be less than 33\%. As per Islamic principal, the company must have more than $67 \%$ permitted traded illiquid assets.

\section{Reason for Islamic mutual funds provide hedging or protection Assets}

Islam encourages business, profit and loss sharing and restrict Riba. Islamic finance (Shariah compliant business) has Asset based financing. Conventional finance has interest-based assets. 2008 crises almost destroyed interest based financial markets and converted into economic depression. 2008 crises did not damage the Islamic financial market, Islamic banking. Many researches have proved that Islamic finance provide best hedging in financial crises. Hesham et al., (2010) concluded further conclude that Islamic mutual funds provide better hedging during economic downturns. They have low value at risk and high sharp ration in crises period. The results confirm that Islamic mutual funds provide hedging opportunity against crises. Zia-ur-Rehman et al. (2015) study confirms Islamic funds performed better in crises period which indicate it provides hedging opportunity. Islamic finance has growing rapidly across world. New venues of Islamic finance are being created and studied regular basis.

\section{Data And Methodology}

In this section, data and method of the proposed study is discussed. This section has been divided into two parts. First part deals with definition and formulas of data while second part deals with the basic methodology that we are used in this study.

\section{Data}

To attain the objective of the study secondary annual data of return of mutual funds, return of benchmark and risk-free rate of conventional and Islamic mutual funds have been collected for the period 2007 to 2016 from MUFAP (www.mufap.com.pk), State Bank of Pakistan (www.sbp.org.pk) and Pakistan Stock Exchange (www.psx.com.pk). Data of 
Macro-economic variables collected from website of World Bank (https://data.worldbank.org/) and Pakistan Bureau of Statistics (www.pbs.gov.pk).

Risk Adjusted Performance: While Beta calculation for each index is important to show the overall correlation of Islamic Index and its counterpart, it does not account for the risk associated with a portfolio that invests in the index. Since the Islamic indices and conventional indices are not from the same category of risk, to make actual comparison we need to convert raw returns to risk adjusted return, it's necessary to utilize the Capital Asset Pricing Model (CAPM) to estimate the risk-adjusted returns (Hussein, 2005). There are three kind of well-known riskadjusted performance measurements used by researchers to examine the performance of the index. These methods are:

1. Sharpe Ratio ---- It takes total risk as referred to standard deviation in denominator

2. Treynor Ratio ---- It takes market risk as referred to Beta in denominator

3. Jensen Alpha

Systematic risk (Beta): Beta specifically is a measure of the volatility, or systematic risk, of a security or portfolio in refer to market risk. Beta is calculated as a factor in the Capital Asset Pricing Model (CAPM) as represented below:

$\mathrm{E}(\mathrm{Ri})=\mathrm{Rf}+\beta[\mathrm{E}(\mathrm{Rm})-(\mathrm{Rf})]$

Where $\mathrm{E}(\mathrm{Ri})$ represents the expected return of the index, Rf represents the risk-free rate, $\mathrm{Rm}$ is the expected return on the market. For risk free rate of Pakistan, this study uses Treasury Bills of Pakistan Government for risk free rate.

Risk Free Rate: The risk-free rate of return is the hypothetical rate of return of an investment without risk. The risk-free rate denotes the interest an investor would expect from a riskfree investment over a specified period of time. In theory, the risk-free rate is the lowest return an investor expects for any investment because he / she will not accept additional risk unless the potential rate of return is greater than the risk-free rate. In practice, however, the risk-free rate does not exist because even the safest investments carry a very small amount of risk. Thus, the interest rate on a three-month T-bills auction rate (Issued by SBP) often used as the risk-free rate for Pakistan based investors.

Total Risk: Every investment has broadly two kinds of risk, Systematic risk and unsystematic risk. Systematic risk is market specific risk and Unsystematic risk is firm or segment specific risk.

\section{Methodology}

In this section we will briefly discuss the method we used in the study. When we evaluate the performance of a portfolio with risk that differs from that of a benchmark, we need to adjust the portfolio returns for the risk of the portfolio. There are several measures of risk-adjusted returns that are used to evaluate relative portfolio performance. One such measure is the Sharpe ratio.

Sharp Ratio: The true measurement of return is important to evaluate performance of Portfolio manager. In addition to return, analyst must weight risk of portfolio. By considering the risk, Analyst measure the risk adjusted return. The Sharpe ratio is one the tool which measure risk adjusted return, it measures excess return per unit of total portfolio risk. The higher the Sharpe ration, the better it shows risk adjusted performance of portfolio. Sharpe ratio uses total risk, systematic risk and unsystematic risk that the portfolio manager has taken. It is only useful for comparison with Sharpe ratio of another portfolio. 
$\frac{\left(R_{P}-R_{F}\right)}{\sigma}$

$R_{P}=$ Return of portfolio

$R_{F}=$ Risk Free Return

$\sigma=$ Standard Deviation of portfolio (Total Risk), systematic and non-systematic

Two measures of risk-adjusted returns based on systematic risk (beta) rather than total risk are the Treynor measure and Jensen's alpha.

Treynor measure: It measures additional returns per unit of systematic risk, the higher this number, the greater "additional return" being generated by the portfolio.

The Treynor measure is calculated as

$\frac{\left(R_{P}-R_{F}\right)}{\beta_{P}}$

$\beta_{P}=$ Beta of portfolio (systematic risk)

Jensen's alpha: It is well known technique among analyst which is used to measure the riskadjusted performance of an individual security or portfolio (mutual funds) in relation to the projected market return - "which is based on the capital asset pricing model (CAPM)". The higher the alpha, the more a portfolio has earned above the level expected. Jensen's alpha for Portfolio P is calculated as

$\alpha_{P}=R_{P}-\left[R_{F}+\beta_{P}\left[R_{M}-R_{F}\right]\right.$

$\alpha \mathrm{P}=R_{P}-[\mathrm{Rf}+\beta \mathrm{P}(\mathrm{RM}-\mathrm{Rf})]$

$R_{m}=$ Average market return

Independent t-test: Part of important studies within business and decision-making are the ones related to hypothesis for difference of population parameters; it is testing the difference between two population means. Independent $t$ test is used to compare the two independent groups. It tells us about the significant difference of two groups that whether the two groups are significantly different to each other or not. For independent $t$ test data must be continuous as well as must be normally distributed. Following are the formulas of independent $t$ test when variances of both groups are equal, and variance of both groups are not equal.

i. When Variances of both groups are equal

$$
t=\frac{\bar{x}_{1}-\bar{x}_{2}}{s \sqrt{\left(\frac{1}{n_{1}}+\frac{1}{n_{2}}\right)}}
$$

ii. When Variances of both groups are unequal

$$
t=\frac{\bar{x}_{1}-\bar{x}_{2}}{s_{p} \sqrt{\left(\frac{1}{n_{1}}+\frac{1}{n_{2}}\right)}}
$$


Where:

$s_{p}=\sqrt{\frac{\left(n_{1}-1\right) s_{1}{ }^{2}+\left(n_{2}-1\right) s_{2}{ }^{2}}{n_{1}+n_{2}-2}}$

\section{RESULTS AND DISCUSSION}

In this section of study, we discuss the results and output obtained from the proposed methods. Descriptive tables are presented with different descriptive measures to describe the data regarding proposed hypothesis.

\section{Descriptive Statistics}

Table 1, 2, and 3 shows the descriptive statistics and t-test statistics value and its associated significance value of Sharp ratio, Treynor ratio, Jensen alpha and Returns between conventional mutual funds and its counterpart Islamic mutual funds of income, equity and asset allocation type respectively. In table 1, the result indicates that conventional income mutual funds mean sharp ratio is -0.1525 and Islamic income mutual funds mean sharp ration is -0.8686 which indicate that risk adjusted performance of income mutual funds is better as compare to the Islamic mutual funds. The Treynor ratio and Jensen alpha shows no significant difference among conventional and Islamic mutual funds. Whereas conventional returns are slightly more than their Islamic counterpart however and difference in insignificant.

Table 1: Descriptive statistics of Ratios of mutual fund type "income" of conventional and Islamic

\begin{tabular}{|c|c|c|c|c|c|c|c|c|c|}
\hline & Conv. & Islamic & Conv. & Islamic & Conv. & Islamic & Conv. & Islamic \\
\hline Descriptive Stats & \multicolumn{2}{|c|}{ Sharp Ratio } & \multicolumn{2}{|c|}{ Treynor Ratio } & \multicolumn{2}{|c|}{ Jensen Alpha } & \multicolumn{2}{|c|}{ Returns } \\
\hline Mean & -0.153 & -0.869 & -0.021 & -0.012 & -0.003 & -0.008 & 0.097 & 0.085 \\
\hline Std. Deviation & 1.232 & 0.905 & 0.173 & 0.013 & 0.026 & 0.014 & 0.021 & 0.018 \\
\hline Skewness & 0.575 & -0.501 & 0.575 & -0.503 & 0.758 & -0.395 & 0.209 & -0.729 \\
\hline Kurtosis & 1.403 & -0.616 & 1.404 & -0.621 & 1.730 & -0.362 & 1.291 & -0.219 \\
\hline Minimum & -2.180 & -2.340 & -0.310 & -0.030 & -0.040 & -0.030 & 0.059 & 0.053 \\
\hline Maximum & 2.490 & 0.520 & 0.350 & 0.010 & 0.050 & 0.020 & 0.140 & 0.110 \\
\hline t-test & 1.554 & -1.74 & 0.562 & 1.486 \\
\hline p-value & \multicolumn{2}{|c|}{$(0.136)$} & \multicolumn{2}{|c|}{$(0.865)$} & \multicolumn{2}{c|}{$(0.58)$} & $(0.1530)$ \\
\hline Decision & $\begin{array}{c}\text { No significant } \\
\text { difference }\end{array}$ & $\begin{array}{c}\text { No significant } \\
\text { difference }\end{array}$ & $\begin{array}{c}\text { No significant } \\
\text { difference }\end{array}$ & $\begin{array}{c}\text { No significant } \\
\text { difference }\end{array}$ \\
\hline
\end{tabular}

Table 2 indicates that Islamic Equity mutual funds perform better as compare to its conventional counterpart in terms of risk adjusted basis. Islamic mutual funds perform better but performance is not statically difference as other two ratios shows "Treynor and Jensen alpha" shows same results. In terms of returns, conventional funds are slightly higher than their Islamic counterpart however and difference in insignificant.

Table 3 shows indicates that Islamic Asset allocation mutual funds perform better as compare to its conventional counterpart in terms of risk adjusted basis. Treynor and Jensen alpha shows statically indifference performance. In terms of returns, Islamic funds are slightly better off than their conventional counterpart however and difference in insignificant. 
Table 2: Descriptive statistics of Ratios of mutual fund type "Equity" of conventional and Islamic

\begin{tabular}{|c|c|c|c|c|c|c|c|c|}
\hline & Conv. & Islamic & Conv. & Islamic & Conv. & Islamic & Conv. & Islamic \\
\hline Descriptive Stats & \multicolumn{2}{|c|}{ Sharp Ratio } & \multicolumn{2}{|c|}{ Treynor Ratio } & \multicolumn{2}{|c|}{ Jensen Alpha } & \multicolumn{2}{|c|}{ Returns } \\
\hline Mean & 0.384 & 0.474 & 0.119 & 0.127 & 0.089 & 0.084 & 0.202 & 0.199 \\
\hline Std. Deviation & 1.036 & 1.025 & 0.320 & 0.274 & 0.235 & 0.177 & 0.265 & 0.206 \\
\hline Skewness & -0.920 & -1.640 & -0.919 & -1.640 & -0.840 & -1.677 & -0.862 & -1.434 \\
\hline Kurtosis & 1.334 & 3.700 & 1.330 & 3.700 & 1.130 & 3.686 & 1.197 & 2.971 \\
\hline Minimum & -1.920 & -2.080 & -0.590 & -0.560 & -0.430 & -0.360 & -0.379 & -0.300 \\
\hline Maximum & 1.760 & 1.850 & 0.540 & 0.490 & 0.400 & 0.320 & 0.564 & 0.479 \\
\hline t-test & \multicolumn{2}{|c|}{-0.205} & \multicolumn{2}{|c|}{-0.604} & \multicolumn{2}{|c|}{0.056} & \multicolumn{2}{|c|}{0.039234141} \\
\hline p-value & \multicolumn{2}{|c|}{$(0.839)$} & \multicolumn{2}{|c|}{$(0.95)$} & \multicolumn{2}{|c|}{$(0.956)$} & \multicolumn{2}{|c|}{$(0.969)$} \\
\hline Decision & \multicolumn{2}{|c|}{$\begin{array}{c}\text { No significant } \\
\text { difference }\end{array}$} & \multicolumn{2}{|c|}{$\begin{array}{c}\text { No significant } \\
\text { difference }\end{array}$} & \multicolumn{2}{|c|}{$\begin{array}{c}\text { No significant } \\
\text { difference }\end{array}$} & \multicolumn{2}{|c|}{$\begin{array}{c}\text { No significant } \\
\text { difference }\end{array}$} \\
\hline
\end{tabular}

\section{Crises period (2008 to 2009)}

Table 4, 5, and 6 shows the descriptive statistics and t-test statistics value and its associated significance value of conventional mutual funds and its counterpart Islamic mutual funds of income, equity and asset allocation type respectively in crises period. Table 4 indicates slightly better performance of conventional income mutual fund risk adjusted basis as compare to its counterpart Islamic income mutual fund.

Table 3: Descriptive statistics of Ratios of mutual fund type "Asset Allocation" of conventional and Islamic

\begin{tabular}{|c|c|c|c|c|c|c|c|c|}
\hline & Conv. & Islamic & Conv. & Islamic & Conv. & Islamic & Conv. & Islamic \\
\hline Descriptive Stats & Sharp Ratio & \multicolumn{2}{|c|}{ Treynor Ratio } & Jensen Alpha & \multicolumn{2}{c|}{ Returns } \\
\hline Mean & -0.012 & 0.456 & -0.002 & 0.088 & -0.008 & 0.043 & 0.099 & 0.147 \\
\hline Std. Deviation & 1.075 & 1.122 & 0.172 & 0.217 & 0.127 & 0.102 & 0.135 & 0.102 \\
\hline Skewness & -1.482 & -0.060 & -1.482 & -0.060 & -1.402 & 0.215 & -1.481 & 0.138 \\
\hline Kurtosis & 1.979 & -0.568 & 1.979 & -0.568 & 1.727 & -1.097 & 1.757 & -0.395 \\
\hline Minimum & -2.520 & -1.550 & -0.400 & -0.300 & -0.300 & -0.120 & -0.210 & -0.029 \\
\hline Maximum & 1.010 & 2.060 & 0.160 & 0.400 & 0.110 & 0.200 & 0.234 & 0.308 \\
\hline t-test & -0.999 & \multicolumn{2}{|c|}{-1.08} & -1.043 & -0.9434 \\
\hline p-value & \multicolumn{2}{|c|}{$(0.33)$} & \multicolumn{2}{|c|}{$(0.293)$} & $(0.31)$ & $(0.3573)$ \\
\hline Decision & $\begin{array}{c}\text { No significant } \\
\text { difference }\end{array}$ & \multicolumn{2}{|c|}{$\begin{array}{c}\text { No significant } \\
\text { difference }\end{array}$} & $\begin{array}{c}\text { No significant } \\
\text { difference }\end{array}$ & $\begin{array}{c}\text { No significant } \\
\text { difference }\end{array}$ \\
\hline
\end{tabular}

Table 4: Mean standard deviation and independent t-test results of Income ratios among conventional and Islamic mutual funds during crisis period

\begin{tabular}{|c|c|c|c|c|c|c|}
\hline Ratio & Group & Mean & S.D & t-test & $\mathrm{p}$-value & Decision \\
\hline \multirow{2}{*}{ Return } & Conventional & 0.091 & 0.009 & \multirow{2}{*}{0.022} & \multirow{2}{*}{0.986} & \multirow{2}{*}{ No significant difference } \\
\hline & Islamic & 0.091 & 0.001 & & & \\
\hline \multirow{2}{*}{ Sharp Ratio } & Conventional & -0.888 & 2.887 & \multirow{2}{*}{0.486} & \multirow{2}{*}{0.653} & \multirow{2}{*}{ No significant difference } \\
\hline & Islamic & -2.490 & 4.931 & & & \\
\hline \multirow{2}{*}{ Treynor Ratio } & Conventional & 0.048 & 0.156 & \multirow{2}{*}{0.269} & \multirow{2}{*}{0.801} & \multirow{2}{*}{ No significant difference } \\
\hline & Islamic & 0.023 & 0.045 & & & \\
\hline \multirow{2}{*}{ Jensen Alpha } & Conventional & -0.007 & 0.034 & \multirow{2}{*}{0.601} & \multirow{2}{*}{0.580} & \multirow{2}{*}{ No significant difference } \\
\hline & Islamic & -0.022 & 0.027 & & & \\
\hline
\end{tabular}


Table 5: Mean standard deviation and independent t-test results of Equity ratios among conventional and Islamic mutual funds during crisis period

\begin{tabular}{|c|c|c|c|c|c|c|}
\hline Ratio & Group & Mean & S.D & t-test & p-value & Decision \\
\hline \multirow{2}{*}{ Return } & Conventional & -0.210 & 0.240 & \multirow{2}{*}{-0.251} & \multirow{2}{*}{0.825} & \multirow{2}{*}{ No significant difference } \\
\hline & Islamic & -0.153 & 0.207 & & & \\
\hline \multirow{2}{*}{ Sharp Ratio } & Conventional & -0.242 & 1.047 & \multirow{2}{*}{0.987} & \multirow{2}{*}{0.830} & \multirow{2}{*}{ No significant difference } \\
\hline & Islamic & -0.440 & 1.072 & & & \\
\hline \multirow{2}{*}{ Treynor Ratio } & Conventional & -0.157 & 0.678 & \multirow{2}{*}{0.532} & \multirow{2}{*}{0.962} & \multirow{2}{*}{ No significant difference } \\
\hline & Islamic & -0.181 & 0.440 & & & \\
\hline \multirow{2}{*}{ Jensen Alpha } & Conventional & -0.127 & 0.522 & \multirow{2}{*}{0.575} & \multirow{2}{*}{0.941} & \multirow{2}{*}{ No significant difference } \\
\hline & Islamic & -0.156 & 0.357 & & & \\
\hline
\end{tabular}

Above Table 5 indicates slightly better performance of conventional Equity mutual fund risk adjusted basis as compare to its counterpart Islamic Equity mutual fund.

Table 6: Mean standard deviation and independent t-test results of Asset allocation ratios among conventional and Islamic mutual funds during crisis period

\begin{tabular}{|c|c|c|c|c|c|c|}
\hline Ratio & Group & Mean & S.D & t-test & $\mathrm{p}$-value & Decision \\
\hline \multirow{2}{*}{ Return } & Conventional & -0.144 & 0.093 & \multirow{2}{*}{-2.026} & \multirow{2}{*}{0.180} & \multirow{2}{*}{ No significant difference } \\
\hline & Islamic & 0.013 & 0.059 & & & \\
\hline \multirow{2}{*}{ Sharp Ratio } & Conventional & -0.665 & 1.089 & \multirow{2}{*}{0.951} & \multirow{2}{*}{0.597} & \multirow{2}{*}{ No significant difference } \\
\hline & Islamic & -0.143 & 1.137 & & & \\
\hline \multirow{2}{*}{ Treynor Ratio } & Conventional & -0.207 & 0.339 & \multirow{2}{*}{-0.725} & \multirow{2}{*}{0.509} & \multirow{2}{*}{ No significant difference } \\
\hline & Islamic & -0.031 & 0.248 & & & \\
\hline \multirow{2}{*}{ Jensen Alpha } & Conventional & -0.150 & 0.271 & \multirow{2}{*}{-0.577} & \multirow{2}{*}{0.595} & \multirow{2}{*}{ No significant difference } \\
\hline & Islamic & -0.041 & 0.182 & & & \\
\hline
\end{tabular}

Table 6 indicates slightly better performance of Islamic Asset allocation mutual fund as compare to conventional Asset allocation mutual fund risk adjusted basis.

\section{Non-Crises period (2010 to 2017)}

Table 7, 8, and 9: shows the descriptive statistics of conventional mutual funds and its counterpart Islamic mutual funds of income, equity and asset allocation type respectively in non-crises period.

Table 7 indicates better performance of conventional income mutual fund risk adjusted basis as compare to its counterpart Islamic income mutual fund in non-crises period. Table 8 showing slightly better performance of Islamic Equity mutual fund risk adjusted basis as compare to its counterpart conventional Equity mutual funds. Table 9 indicates better performance of Islamic Asset allocation mutual fund risk adjusted basis as compare to its counterpart Islamic Asset allocation mutual fund in non-crises period.

Table 7: Descriptive statistics of Ratios of mutual fund type "income" of conventional and Islamic in non-crises period.

\begin{tabular}{|c|c|c|c|c|c|c|}
\hline Ratio & Group & Mean & S.D & t-test & p-value & Decision \\
\hline \multirow{2}{*}{ Return } & Conventional & 0.098 & 0.024 & \multirow{2}{*}{1.438} & \multirow{2}{*}{0.172} & \multirow{2}{*}{ No significant difference } \\
\cline { 2 - 5 } & Islamic & 0.082 & 0.020 & & & \\
\hline \multirow{2}{*}{ Sharp Ratio } & Conventional & -0.028 & 1.034 & \multirow{2}{*}{1.818} & 0.094 & \multirow{2}{*}{ No significant difference } \\
\cline { 2 - 4 } & Islamic & -0.831 & 0.699 & & & \\
\hline
\end{tabular}




\begin{tabular}{|l|c|c|c|c|c|l|}
\hline \multirow{2}{*}{ Treynor Ratio } & Conventional & -0.003 & 0.100 & \multirow{2}{*}{0.285} & \multirow{2}{*}{0.784} & \multirow{2}{*}{ No significant difference } \\
\cline { 2 - 5 } & Islamic & -0.013 & 0.011 & & & \\
\hline \multirow{2}{*}{ Jensen Alpha } & Conventional & 0.001 & 0.026 & \multirow{2}{*}{0.501} & \multirow{2}{*}{0.629} & \multirow{2}{*}{ No significant difference } \\
\cline { 2 - 4 } & Islamic & -0.004 & 0.011 & & & \\
\hline
\end{tabular}

Table 8: Descriptive statistics of Ratios of mutual fund type "Equity" of conventional and Islamic in non-crises period.

\begin{tabular}{|c|c|c|c|c|c|c|}
\hline Ratio & Group & Mean & S.D & t-test & p-value & Decision \\
\hline \multirow{2}{*}{ Return } & Conventional & 0.276 & 0.171 & \multirow{2}{*}{-0.044} & \multirow{2}{*}{0.965} & \multirow{2}{*}{ No significant difference } \\
\hline & Islamic & 0.279 & 0.107 & & & \\
\hline \multirow{2}{*}{ Sharp Ratio } & Conventional & 1.035 & 1.028 & \multirow{2}{*}{-1.337} & \multirow{2}{*}{0.203} & \multirow{2}{*}{ No significant difference } \\
\hline & Islamic & 1.689 & 0.929 & & & \\
\hline \multirow{2}{*}{ Treynor Ratio } & Conventional & 0.206 & 0.205 & \multirow{2}{*}{-0.998} & \multirow{2}{*}{0.337} & \multirow{2}{*}{ No significant difference } \\
\hline & Islamic & 0.299 & 0.164 & & & \\
\hline \multirow{2}{*}{ Jensen Alpha } & Conventional & 0.134 & 0.145 & \multirow{2}{*}{0.031} & \multirow{2}{*}{0.976} & \multirow{2}{*}{ No significant difference } \\
\hline & Islamic & 0.132 & 0.068 & & & \\
\hline
\end{tabular}

Table 9: Descriptive statistics of Ratios of mutual fund type "Asset Allocation" of conventional and Islamic in non-crises period

\begin{tabular}{|c|c|c|c|c|c|c|}
\hline Ratio & Group & Mean & S.D & t-test & p-value & Decision \\
\hline \multirow{2}{*}{ Return } & Conventional & 0.148 & 0.062 & \multirow{2}{*}{-0.581} & \multirow{2}{*}{0.571} & \multirow{2}{*}{ No significant difference } \\
\hline & Islamic & 0.170 & 0.087 & & & \\
\hline \multirow{2}{*}{ Sharp Ratio } & Conventional & 0.798 & 1.121 & \multirow{2}{*}{-0.036} & \multirow{2}{*}{0.972} & \multirow{2}{*}{ No significant difference } \\
\hline & Islamic & 0.818 & 1.121 & & & \\
\hline \multirow{2}{*}{ Treynor Ratio } & Conventional & 0.118 & 0.166 & \multirow{2}{*}{-0.618} & \multirow{2}{*}{0.548} & \multirow{2}{*}{ No significant difference } \\
\hline & Islamic & 0.184 & 0.253 & & & \\
\hline \multirow{2}{*}{ Jensen Alpha } & Conventional & 0.028 & 0.060 & \multirow{2}{*}{-0.645} & \multirow{2}{*}{0.531} & \multirow{2}{*}{ No significant difference } \\
\hline & Islamic & 0.053 & 0.091 & & & \\
\hline
\end{tabular}

\section{Independent t-test}

In this section of study, we analyze the difference among conventional and Islamic mutual funds. In t test, we consider the risk adjusted return of sharp ratio, Treynor ratio and Jensen alpha of income, equity and asset allocation mutual funds as a dependent variables and conventional and Islamic financial institutions as an independent's variable. We compare the significance value of the test statistics at 0.05 level of significance, if our significance value is less than our desire level of significance we assume that there is a significant difference among conventional and Islamic mutual funds on this ratio. However, due to robustness of the data we cannot rely only on the significance value and we also make the decision using mean and standard deviation.

In Table 1, the test statistics value of sharp ratio is found to be 1.554 and its associated significance value is 0.136 . This indicates that there is no significance difference among sharp ratios of conventional and Islamic mutual funds. However, the mean value of sharp ratio of conventional mutual funds shows slightly better performance compare to the Islamic mutual funds regarding risk adjusted basis. The test statistics and significance value of Treynor ratio and Jensen alpha are also shows no significant difference among conventional and Islamic mutual funds. This result is consistence with other results. The mean and standard deviation of both measures also depicts the same picture. This can be taken to mean that conventional 
mutual funds perform somewhat better in terms of risk adjusted basis compare to the Islamic mutual funds, but difference is not significant. Similarly, in Table 2 the test statistics value of sharp ratio is found to be -0.205 and its associated significance value is 0.839 . This indicates that there is no significance difference among sharp ratios of conventional and Islamic mutual funds. However, the mean value of sharp ratio of Islamic equity mutual funds shows slightly better performance as compare to the conventional equity mutual funds regarding risk adjusted basis. The test statistics and significance value of Treynor ratio and Jensen alpha are also shows no significant difference among conventional and Islamic mutual funds. This result is consistence with descriptive statistics result. The mean and standard deviation of both measures also depicts the same picture. Table 3 shows that the test statistics value of sharp ratio is found to be -0.999 and its associated significance value is 0.330 . This indicates that there is no significance difference among sharp ratios of conventional and Islamic mutual funds. However, the mean value of sharp ratio of Islamic equity mutual funds shows slightly better performance as compare to the conventional equity mutual funds regarding risk adjusted basis. The test statistics and significance value of Treynor ratio and Jensen alpha are also shows no significant difference among conventional and Islamic mutual funds. This result is also consistence with other results.

\section{Crisis Period (2008-2009)}

In table 4, the test statistics and significance value of Treynor ratio and Jensen alpha in all the tables shows no significant difference among conventional and Islamic mutual funds of income type. This result is consistence with above descriptive stats of crises period. However, the test statistics value of sharp ratio and its associated significance value shows slightly better performance of all conventional Income mutual funds in crisis period as compare to all Islamic income mutual funds, but difference is not significant. In Table 5, the test statistics value of sharp ratio and its associated significance value show statically indifference between conventional Equity mutual funds in crisis period as compare to Equity Islamic mutual funds. The test statistics and significance value of Treynor ratio and Jensen alpha are also shows no significant difference among conventional and Islamic Equity mutual funds. In Table 6, the test statistics value of sharp ratio and its associated significance value show better performance of Islamic Asset allocation mutual funds in crisis period as compare to Asset allocation Islamic mutual funds, but difference is not significant. The test statistics and significance value of Treynor ratio and Jensen alpha are also shows no significant difference among conventional and Islamic Asset allocation mutual funds.

\section{Non-Crisis Period (2010-17)}

In Table 7, the test statistics value of sharp ratio is found to be 1.438 and its associated significance value is 0.172 . This indicates that there is no significance difference among sharp ratios of conventional and Islamic Income mutual funds in non-crises periods. However, the mean value of sharp ratio of conventional mutual funds shows slightly better performance compare to the Islamic mutual funds regarding risk adjusted basis. The test statistics and significance value of Treynor ratio and Jensen alpha are also shows no significant difference among conventional and Islamic mutual funds. This result is consistence with other results. The mean and standard deviation of both measures also depicts the same picture. This can be taken to mean that conventional mutual funds perform somewhat better in terms of risk adjusted basis compare to the Islamic mutual funds in noncrises period, but difference is not significant. 
In Table 8 , the test statistics value of sharp ratio is found to be -0.44 and its associated significance value is 0.952 . This indicates that there is no significance difference among sharp ratios of conventional and Islamic equity mutual funds in non-crises periods. However, the mean value of sharp ratio, Treynor ratio and Jensen alpha all slightly better performance of Islamic equity mutual funds as compare to the conventional funds regarding risk adjusted basis. The test statistics and significance value of Treynor ratio and Jensen alpha are also shows no significant difference among conventional and Islamic equity mutual funds. This result is consistence with other results. The mean and standard deviation of both measures also depicts the same picture. This can be taken to mean that Islamic mutual funds perform somewhat better in terms of risk adjusted basis as compare to the conventional mutual funds in non-crises period, but difference is not significant.

In Table 9, the test statistics value of sharp ratio is found to be -0.581 and its associated significance value is 0.571 . This indicates that there is no significance difference among sharp ratios of conventional and Islamic Asset Allocation mutual funds in non-crises periods. However, the mean value of sharp ratio, Treynor ratio and Jensen alpha all slightly better performance of Islamic Asset Allocation mutual funds as compare to the conventional funds regarding risk adjusted basis. The test statistics and significance value of Treynor ratio and Jensen alpha are also shows no significant difference among conventional and Islamic mutual funds. This result is consistence with other results. The mean and standard deviation of both measures also depicts the same picture. This can be taken to mean that Islamic mutual funds perform somewhat better in terms of risk adjusted basis as compare to the conventional mutual funds in non-crises period, but difference is not significant.

\section{Conclusion ANd RECOMmEndATION}

\section{Conclusion}

In the last section, conclusion is drawn based on all results obtained in the previous chapters and some recommendations are given based on this conclusion. This study attempts bifurcated study in three periods, Crises period (2008 to 2009) and Whole period (2007 to 2017) and non-crises period (2010 to 2017) each period we compare the performance of three different type of convention mutual funds with same type mutual funds of Shariah compliant specification. Study found that conventional Income mutual funds outperform in all three periods, whole period, crises period and non-crises period as compare to its counterpart Islamic income mutual funds in both risks adjusted basis and simple arithmetic mean basis. Study also found that Islamic equity mutual funds outperform in in all three periods, whole period, crises period and non-crises period as compare to its conventional equity mutual funds in risk adjusted basis. In whole period performance is slightly better which is not statically difference but in crises period both mutual funds gave negative return, but Islamic equity mutual funds declined less than conventional mutual funds which shows that Islamic mutual funds provide better hedging in crises period, in non-crises period also, Islamic Equity mutual fund perform better as per risk adjusted basis. Islamic asset allocation mutual funds outperform conventional asset allocation mutual funds in in in all three periods, whole period, crises period and non-crises period as compare to its conventional Asset Allocation mutual funds risk adjusted basis.

\section{Significance of the Study}

This research will provide opportunity for investor to investigate 6 main types of mutual funds, 3 from conventional and Islamic mutual funds. Furthermore, studied mutual fund 
analyzed from three period, namely, crises, non-crises, and whole period. Objective of Investor of Islamic mutual funds not only maximize their wealth but satisfaction of getting Halal return is tied with their objectives. And this type of investors is more loyal with Asset management companies than conventional investor as conventional investors' primary objective to maximize their wealth on risk basis.

\section{Implications}

The finding proposed that the performance of the Islamic indices does not differ from that of their conventional counterparts in all non-crisis's periods and whole period but in crises period Islamic indices absorbed shock. This is main thing for investor who are seeking hedging stock to protect investment in financial crunch or abnormal shocks.

\section{Recommendation}

Based on the results of Sharp Ratio, Treynor ration Jensen alpha, t-test and regression, shows the performance of Islamic mutual fund is better than conventional mutual funds. From these results, the Islamic Equity mutual fund (Shariah compliant mutual fund) may be an option for investors to invest, but those investors who want to invest in fixed income mutual funds, for them conventional income mutual fund is better option.

\section{REFERENCES}

Abderrezak, F. (2008). The performance of Islamic equity funds: A comparison to conventional. Islamic and ethical benchmarks, Retrieved April 1: 2010.

Banani, A. and Hidayatun, N. A. (2017). Performance of Islamic indices: risk adjusted returns of shariah compliant stocks on Jakarta Islamic index and Dow Jones Islamic turkey. Journal of Economics $\mathcal{E}$ Business, Vol. 01, No. 01 (April-2017) 001-018.

Beck, T., A. Demirgüç-Kunt and O. Merrouche, (2013). Islamic Vs. Conventional Banking: Business Model, Efficiency and Stability. Journal of Banking and Finance, Vol. 37, 433-447.

Bilal Nafees, Muhammad Ali Jibran Qamar, Nisar Ahmad (2018). Lucrativeness of Islamic vs conventional mutual funds in Pakistan. Pakistan Business Review Jan 2018. JEL Calcification: G 230.

Dharani, M. and Natarajan, P. (2011). Seasonal Anomalies between S\&P CNX Nifty Shariah Index and S\&P CNX Nifty Index in India. Journal of Social and Development Sciences. Vol. 1, No. 3, 101-108.

Elfakhani, S., Hasan, M. K., \& Sidani, Y. (2005). Comparative performance of Islamic versus secular mutual funds. Paper presented at the $12^{\text {th }}$ Economic Research Forum, University of New Orleans, US.

Fikriyah Abdullah, Taufiq Hassan, Shamsher Mohamad (2007). Investigation of performance of Malaysian Islamic unit trust funds: Comparison with conventional unit trust funds. Managerial Finance, 33(2): 142-153.

Hayat, R. and R. Kraeussl (2011). Risk and return characteristics of Islamic equity funds. Emerging Markets Review, 12(2): 189-203.

Hesham Merdad, M. Kabir Hassan and Yasser Alhenawi (2010). Islamic Versus Conventional Mutual Funds Performance in Saudi Arabia: A Case Study. JKAU: Islamic Econ., Vol. 23 No. 2, 157-193.

Hoepner, A. G. F. \& Mcmillan, D. G. (2009). Responsible Investment: An Influential Literature Analysis comprising a rating, characterization, categorization \& investigation. Available: http:/ / papers.ssrn.com/sol3/papers.cfm?abstract_id=1454793 [Accessed 2017, September 6].

Hussein, K. (2005). Islamic investment: Evidence from Dow Jones and FTSE

Hussein, K. and Omran, M. (2005). Ethical Investment revisited: Evidence from Dow Jones Islamic Indexes. The Journal of Investing. 105-124. 
Issam BOUSALAM, Moustapha HAMZAOUI (2016). Impact of Ethical Screening on Risk and Returns: The Case of Constructed Moroccan Islamic Stock Indexes. MPRA Paper No. 68979, posted 23 January 2016 11:26 UTC.

Mohsina Habib, Khalid Ul Islam, (2014). An Empirical Assessment of Islamic Index: A Case Study of India. IRACST- International Journal of Research in Management \& Technology (IJRMT), ISSN: 22499563, Vol.4, No.3.

Nasir Razzaq, Sajid Gul1, Muhammad Sajid, Sumra Mughal, Syeda Asma Bukhari, (2012). Performance of Islamic Mutual Funds in Pakistan. Economics and Finance Review, Vol. 2(3) pp. 16, ISSN: 2047 0401.

Osamah M. Al-Khazali, Guillaume Leduc, Mohammad Saleh Alsayed (2015). A Market Efficiency Comparison of Islamic and Non-Islamic Stock Indices. Emerging Markets Finance and Trade, Volume 52, Pages 1587-1605.

Saud Ahmed Khan, Muhammad Khaleequzzaman, Muhammad Ishfaq, Shahan Zeb Khan (2017). Comparative Risk and Return Analysis of Islamic and Conventional Financial Institutions in Pakistan. International journal of Islamic economics and finance studies, Vol: 3, Issue: 1, p-ISSN: 21498407.

Sejarah, A. (2015). How performance of Jakarta Islamic index (JII) stocks relative to other stocks?.Jurnal Dinamika Manajemen, JDM Vol. 6, No. 2, 2015, 145-164.

Shaliza Alwi, Rosimah Ahmad, Irma Zura Amir Hashim, Norbaizura Mohd Naim (2017). Investigating the Islamic and Conventional Mutual Fund Performance: Evidence from Malaysia Equity Market. International Conference on Management and Information Systems.

Statman, M. (2000). Socially responsible mutual funds. Financial Analysts Journal. Vol 56 (3), 30-39.

Yacine Hammami, Abdel monem Oueslati (2017). Measuring skill in the Islamic mutual fund industry: Evidence from GCC countries. Journal of International Financial Markets, Institutions and Money, Volume 49, Pages 15-31.

Zia-ur-Rehman Rao, Muhammad Zubair Tauni, Amjad Iqbal, (2015). Comparison between Islamic and general Equity Funds of Pakistan: Difference in their performances and Fund Flow Volatility. Emerging Economy Studies. Vol 1(2) 211-226. 